\title{
COMPARISON OF NUTRITIONAL STATUS BETWEEN KINDERGARTEN GROUPS IN SPLIT
}

\author{
NELA ŽIDIĆ ${ }^{1}$ NADA TOMASOVIĆ MRČELA ${ }^{2,3}$
}

Aim: to determine whether there is a difference in the level of nutritional status of children across age groups, which would indicate the need for a change in caloric values of daily menus that are currently the same for all age groups in kindergartens in Split.

Participants and methods: The study was conducted during June 2020 in "Grigor Vitez" kindergarten in Split. All parents were asked to voluntarily complete a questionnaire with a guarantee of anonymity. The data on height and weight of children were used to calculate the nutritional indicators: the body mass index (BMI) and the percentile curves of the body mass index (\% BMI), defined by gender and age.

Results: Data for 128 children aged 3-6.99 of the kindergarten "Grigor Vitez" were analyzed. Children in the selected kindergartens did not differ significantly in relation to the level of their nutritional status across age groups (3-3.99 years, 4-4.99 years, 5-5.99 years, 6-6.99 years). The highest average percentile was determined (60.30) in the age group of children aged 6.00-6.99, which is 12.89 points higher than the average value of the percentile of children aged 3.00-3.99 years, while no difference was found by testing $(F=0.936 ; p=0.426)$.

Conclusion: Only percentile values were compared between kindergarten groups, and so it can be concluded that meals may have appropriate energy values, which should be checked by analyzing the menus, and comparing them with the recommendations.

Keywords: NUTRITIONAL STATUS OF PRESCHOOL CHILDREN, KINDERGARTEN MENUS

\section{INTRODUCTION}

Balanced and adequate nutrition at preschool age is extremely important for a child's physical growth and mental development (1). It is therefore essential to have a collaboration between the head of healthcare services and preschool teachers in health education, especially when choosing foods for planning meals for children in the nursery or kindergar-

${ }^{1}$ University Hospital of Split, Croatia ${ }^{2}$ Referral Center of the Ministry of Health for Health Care of the Elderly - Department of Public Health Gerontology, Andrija Štampar Teaching Institute of Public Health, Zagreb, Croatia

${ }^{3}$ University of Split,

Department of Health Studies, Croatia

\section{Address:}

Assistant Prof. Nada Tomasović Mrčela, MD, PhD Referral Center of the Ministry of Health for Health Care of the Elderly - Department of Public Health Gerontology, Andrija Štampar Teaching Institute of Public Health, Zagreb, Croatia 10000 Zagreb, Mirogojska cesta 16 E-mail: nada.tomasovic-mrcela@stampar.hr ten programs. It is necessary to ensure an adequate meal schedule and a specified daily energy intake for children aged 1-6 who spend a significant portion of their day in the kindergarten.

Obesity and malnutrition in children as two extremes in the nutritional status can occur due to an inadequate energy intake (2). Therefore, it is necessary to apply dietary norms and standards found in the Program of health care, hygiene, and healthy nutrition for preschool children (3). The focus is put on the seasonal choice of certain foods and the recommended daily intake of nutrients and energy for the child's age to ensure a balanced and healthy diet for children in kindergartens. Special attention is directed to nutritional allergies or food-related autoimmune diseases in certain children. The meal plan is created based on the length of the child's stay in the kindergarten during the day (5-hour, 6-hour, 7-hour or 10-hour program) (4).
Malnutrition presents itself as a lack of acquired body weight i.e., an imbalance in the human body caused by poor or reduced consumption of energy from nutrients and food $(1,5)$. Malnourished children characteristically have poor appetite, are dissatisfied and passive (6). On the other hand, obesity is a 21 st century public health problem characterized by excessive or abnormal accumulation of fat in an individual with a negative impact on health $(7,8)$. Obesity in children is a risk factor for the occurrence of obesity in adulthood, which then increases the risk of developing cardiovascular diseases, diabetes, and other comorbidities (9). Factors that contribute to development of obesity can be genetic, environmental, social, psychological, cultural, or economic $(7,9)$. Among the most significant causes of obesity, we can single out hereditary traits, psychological reasons, eating disorders, poor physical activity, certain medications, various diseases, and hormonal causes (7). 
It is a worrying fact that the share of children who were overweight in Croatia in 2015 was as high as $34.9 \%$, of which $14 \%$ were obese (10). It is also alarming that in the last 12 years the share of overweight and obese children has increased by $15 \%$ (10). Anthropometric indicators (body weight and height, upper arm circumference, waist, and hip circumference, etc.) are used to diagnose malnutrition or obesity in children (6). Body mass index (BMI) is particularly important for determining obesity, its reliability being based on the good correlation between body fat percentage and the BMI (6). The formula for calculating the Body Mass Index is $\mathrm{BMI}=\mathrm{kg} / \mathrm{m}^{2}$ and is calculated by dividing the person's body weight (in kilograms) by the square of the person's height (in meters) (11). The World Health Organization classifies obesity in children according to the z-value for BMI: ITM-z +2 SD standard deviation (SD) indicates being overweight, and ITM-z +3 SD indicates obesity (9). The National Center for Health Statistics / Center for Disease Control and Prevention (NCHC/CDS) has a classification system according to which there is an increased risk of obesity for children whose BMI is between the 85th and 95th percentile for age and gender, and obese children are those whose BMI is $\geq 95$ th percentile for age and sex (9).

This research is aimed at examining the existence of differences in the level of nutritional status of children in 4 age groups (3-3.99 years, 4-4.99 years, 5-5.99 years, 6-6.99 years), which would imply the need to change the caloric values of daily menus in kindergartens.

\section{PARTICIPANTS AND METHODS}

This research was conducted as part of the diploma thesis titled "The importance of nutrition conditions of preschool children to make a menu in a kindergarten" (in Croatian) by Nela Židić and mentored by Nada Tomasović Mrčela (12).

The research was conducted in June 2020 in the Kindergarten "Grigor Vitez" (kindergarten facilities "Milo dijete", "Ivančica", "Vedri dani", "Maslačak", "Drveni lutak", "Golubica", "Sretni princ" and "Frulica") in Split. All parents were asked to voluntarily complete a survey questionnaire with guarantee of anonymity. Data obtained from parents on the height and weight of the child were used to calculate the nutritional indicators: body mass index (BMI) and percentile curves of the body mass index (\%BMI), defined by gender and age. (Hereinafter: percentiles).

BMI Percentile Calculator for Child and Teen was used to calculate the results (13). In this way, the group of malnourished children included participants up to the 5th percentile, the group of children with normal weight from the 5th to the 85 th percentile, followed by the group of overweight children from the 85 th to the 95th percentile, and the group of obese children above the 95 th percentile.

Parents filled out questionnaires for 136 out of a total of 746 children in the "Grigor Vitez" Kindergarten, which is a response rate of $18.23 \%$. This study included 128 children in the age group of from 3 to 6.99 years (23 from kindergarten facility "Milo dijete", 17 from "Ivančica", 19 from "Vedri dani", 19 from "Maslačak", 14 from "Golubica", 10 from "Drveni lutak", 14 from "Sretni princ" and 12 from "Frulica"). Based on the exclusion criteria, the data of 8 children aged 7 and over were not statistically processed.

Methods of descriptive statistics such as arithmetic mean and standard deviation were used, while median as central value and interquartile range as dispersion indicator were used in case of non-fulfillment of conditions of normal distribution. The structure of participants according to their age is presented in absolute and percentage frequencies. The Kolmogorov-Smirnov test examined the normality of the distribution. Numerical values are presented using the arithmetic mean and standard deviation as indicators of deviation. The ANOVA test was used to examine the difference in the average values of BMI and percentiles of children - participants by age. We used the Spearman correlation coefficient to measure the correlation between the body mass index and age, and the correlation between the percentile of nutritional status and age.

\section{RESULTS}

In this study, the most frequent respondents to the questionnaire were mothers with a share of $85.15 \%(\mathrm{~N}=86)$ versus $14.85 \%(\mathrm{~N}=15)$ of fathers. The representation of male children who participated in this study is higher $(63.52 \%)$ in comparison to female children $(57.48 \%)$. The distribution of the children-participants according to age groups is as follows (Table 1):

Table 1.

Distribution of children - participants in kindergartens based on age groups

\begin{tabular}{lll}
\hline Age group & $\mathrm{N}$ & $\%$ \\
\hline $3.00-3.99$ & 20 & $15.75 \%$ \\
$4.00-4.99$ & 36 & $28.35 \%$ \\
$5.00-5.99$ & 40 & $31.50 \%$ \\
$6.00-6.99$ & 31 & $24.41 \%$ \\
\hline
\end{tabular}

The mean age of the surveyed children was 5.08 years with an interquartile range of 1.59 years $(\mathrm{IQR}=4.33-5.92)$. BMI index was obtained using data on the height and weight of children; average value of the index was 15.68 with a standard deviation of 1.63 . No correlation was found when testing the correlation between body mass index and age $(\mathrm{r}=-0.06 ; \mathrm{p}=0.518)$. Also, no correlation was found when testing the association between the percentile of nutritional status and age $(\mathrm{r}=0.12 ; \mathrm{p}=0.188)$. The research question was whether there is a difference in nutritional status among kindergarten children depending on age group (3-3.99 years, 4-4.99 years, 5-5.99 years, 6-6.99 years). Participants (children) were divided into 4 groups according to age, as follows (Table 2):

The highest average BMI (15.91) was determined in the group of children aged 3.00-3.99, which was 0.37 points higher than the average BMI of children aged 6.00-6.99. However, no difference was found by testing $(\mathrm{F}=0.25 ; \mathrm{p}=0.862)$ (Table 2).

The highest average percentile (60.30) was determined in the group of children aged 6.00-6.99, which is 12.89 
Table 2 .

Overview of the average BMI of children-participants by age

\begin{tabular}{llllll}
\hline Age & $\mathrm{N}$ & Average & SD & $\mathrm{F}$ & $\mathrm{p}^{*}$ \\
\hline $3.00-3.99$ & 20 & 15.91 & 2.07 & 0.25 & 0.862 \\
$4.00-4.99$ & 32 & 15.59 & 1.46 & & \\
$5.00-5.99$ & 35 & 15.76 & 1.75 & & \\
$6.00-6.99$ & 29 & 15.54 & 1.39 & & \\
\hline
\end{tabular}

*F test (ANOVA)

Table 3.

Representation of average percentiles of children - participants by age

\begin{tabular}{llllll}
\hline Age & $\mathrm{N}$ & Average & SD & F & $\mathrm{p}^{*}$ \\
\hline $3.00-3.99$ & 20 & 47.41 & 36.61 & 0.936 & 0.426 \\
$4.00-4.99$ & 32 & 50.06 & 33.72 & & \\
$5.00-5.99$ & 35 & 57.37 & 32.01 & & \\
$6.00-6.99$ & 29 & 60.30 & 4.18 & & \\
\hline
\end{tabular}

*F test (ANOVA)

points higher than the average value of the percentile of children aged 3.00-3.99 years, while no difference was found by testing $(\mathrm{F}=0.936 ; \mathrm{p}=0.426)$ (Table 3$)$.

\section{DISCUSSION}

Current discussions on the prevalence of childhood obesity show the importance of research aimed at nutrition of children in kindergartens and schools. Recent data (2015) show that more than a third of children in Croatia are overweight and obese, which shows the necessity for public-health interventions at the national level (10). The results of this study conducted in kindergartens in Split show that the highest average percentile (60.30) was found in children aged 6.00-6.99 years.

The global public health challenge is demonstrated in the growing number of school-age children who are obese or overweight, and such trend is followed by preschool children in many countries, as indicated by Canning, Courage and Frizzell (14). They calculated the BMI using data on the height and weight of children born in 1997 during the Preschool Health Check Program in the Canadian provinces of Newfoundland and Labrador in the period 2000-2003, and the results of their study showed that the share of as many as $25.6 \%$ of 4,161 children aged 3-5 were obese or overweight (14).

The incidence of childhood obesity has become more frequent in the last ten years (15). The reasons for this are mainly found in inadequate diet and a sedentary lifestyle that often includes hours of watching television and playing on the computer $(15,16)$. Taking these changes in life habits into account, it is important to engage children in physical activities at an early age. This will positively affect not only the normal development and growth of the child but also the quality of physical as well as mental health (with higher self-esteem and self-confidence, and lower occurrence of depression and anxiety) $(16,17)$. A positive attitude and motivation for physical activity in children is best achieved with the support and example of adults, especially parents and teachers (16).

In Croatian kindergartens, nurses integrate their professional knowledge in a multidisciplinary team to provide optimal conditions necessary for children's development, preservation of health and childcare in the educational process (18). In accordance with the "Program of he- alth care, hygiene, and healthy nutrition for preschool children", the role of the nurse is to apply methods and manners of integrated approach to work to perform their primary tasks within children's health care as well as fulfilling their role within the educational system $(4,18)$. Nurse with a university degree is also the head of healthcare services in a kindergarten in accordance with the National Pedagogical Standard for Preschool Education (19). In this way, the nurse, along with professional collaborators (preschool teachers, principals, and others) and parents, participates in ensuring and improving the protection of children's health (19). This study highlights the role of the nurse who provides an expert answer to frequent and current questions about the nutritional status of children in kindergartens, which also includes the creation of menus and the adequacy of diet in preschool institutions.

The recommendations of the "Program of health care, hygiene, and healthy nutrition for preschool children" emphasize the needed type and schedule of daily meals (early breakfast, breakfast, lunch, snack, and dinner) that are adapted to the length of children's stay in kindergarten (4). The bodies of children aged 1-6 should be supplied with nutrients, energy, minerals and vitamins, and fluids. They should eat cereals, milk and dairy products, vegetables, fruits, and water each day, while the recommendation is to eat eggs up to three times a week, meat up to five times a week, fish once or twice a week, and refined food products as rarely as possible and in small quantities $(3,4$, 20). Food is prepared in such a way that its nutritional value (vitamins, minerals) is preserved, i.e., so that the food is not destroyed by heat but preserves the necessary nutrients, while avoiding salt, concentrated sugars, and unhealthy additional fats. Special attention should be paid to adapting food to children's age which also includes serving it in an appealing manner (for example by using various shapes and colors of dishes) (3).

The risk of obesity and the development of chronic diseases such as diabetes, diseases of the heart and the blood vessels is reduced by physical exercise $(15,21)$. Therefore, exercising should be 
introduced as early as possible in preschool age, since it is necessary for the proper development and growth of the child as well as for the acquisition of positive health habits $(15,21)$. It is particularly important that children's desire and need for cooperation and play with their peers is met through physical exercise (21).

This study points to the necessity of continuous implementation of preventive educational health programs which would include determining the actual nutritional status of children, the possibility of improving the menus and creating healthy lifestyle habits from an early age in kindergartens. Special emphasis is placed on the cooperation of the head of healthcare services, principal, cook, preschool teacher, psychologist, pedagogue, technical staff, and parents of the preschool child, which is necessary to optimally approach the preventive, educational, communicational, and organizational aspects of kindergarten nutrition $(3,22)$. The limitation of this research is possible recall bias of the parents who had to answer questions about their children's weight and height.

\section{CONCLUSION}

The results of this study showed that children in the surveyed kindergarten "Grigor Vitez" in Split do not differ significantly in the level of nutritional status across age groups (3-3.99 years, 4-4.99 years, 5-5.99 years, 6-6.99 years). Only percentile values were compared between kindergarten groups, and it can be concluded that meals may have appropriate energy values, which should be checked by analyzing the menus, and comparing them with the recommendations.

\section{Abbreviations:}

(BMI) - body mass index

(SD) - standard deviation

(\% BMI) - percentile curves of the body mass index, defined by gender and age (percentiles) kcal - (kilokalorija)

(DV) - dječji vrtić

(ITM) - indeks tjelesne mase

(\% ITM) - percentilne krivulje indeksa tjelesne mase, definirane prema spolu i uzrastu (percentili)

\section{NOVČANA POTPORA/FUNDING}

Nema/None

\section{ETIČKO ODOBRENJE/ETHICAL APPROVAL Nije potrebno/None}

\section{SUKOB INTERESA/CONFLICT OF INTEREST}

Autori su popunili the Unified Competing Interest form na www.icmje.org/coi_disclosure.pdf (dostupno na zahtjev) obrazac i izjavljuju: nemaju potporu niti jedne organizacije za objavljeni rad; nemaju financijsku potporu niti jedne organizacije koja bi mogla imati interes za objavu ovog rada u posljednje 3 godine; nemaju drugih veza ili aktivnosti koje bi mogle utjecati na objavljeni rad./ All authors have completed the Unified Competing Interest form at www.icmje.org/coi_disclosure. $p d f$ (available on request from the corresponding author) and declare: no support from any organization for the submitted work; no financial relationships with any organizations that might have an interest in the submitted work in the previous 3 years; no other relationships or activities that could appear to have influenced the submitted work.

\section{LITERATURE}

1. Percl M. Prehrana djeteta: Kako pravilno hraniti dijete od začeća do adolescencije. Zagreb: Školska knjiga; 1999.

2. Gazec P. Prehrambene navike djece predškolske dobi (final thesis). Bjelovar: Polytechnic in Bjelovar; 2018 (Internet). (accessed on 24 Sep 2019). Available at: https://zir.nsk.hr/islandora/ object/vtsbj:278/preview

3. Vučemilović Lj, Šisler Vujić Lj, ed. Preporuke i smjernice za stručnjake koji rade na planiranju i pripremanju prehrane djece u dječjem vrtiću. (Internet). Zagreb: Laser plus ltd.; 2007. (accessed on 21 Sep 2019). Available at: http:// www.godineprve.eu/Brosure/Prehrana $\% 20$ u\%20predskolskoj\%20dobi/prehrambeni\%20 standardi\%20za\%20planiranje \%20prehrane\%20u\%20djecjim\%20vrticima.pdf

4. Ministry of Health and Social Welfare. Amendments to the Program of Health Care, Hygiene and Healthy Nutrition of Preschool Children. (in Croatian). Zagreb: MZSS. NN 121/07; 2007. (accessed on 24 Sep 2019). Available at: https://narodne-novine.nn.hr/clanci/sluzbeni/2007_11_121_3527.html

5. World Health Organization. Malnutrition. (Internet). Geneva: WHO; 2020. (accessed on 28 Mar 2020). Available at: https://www.who.int/ topics/malnutrition/en/

6. Pandžić S. Procjena prehrane i životnih navika djece predškolske dobi (diploma thesis). Osijek: Faculty of Food Technology, 2015. (Internet). (accessed on 08 Sep 2019). Available at: https://repozitorij.ptfos.hr/islandora/object/ ptfos:556/preview

7. Hajdić S, Gugić T, Bačić K, Hudorović N. Prevencija pretilosti u dječjoj dobi. Nurses Gazette; (Internet). 2014. (accessed on 29 Mar 2020); 19: 239- 41. Available at: https://hrcak.srce.hr/index.php?id_clanak_ jezik $=191801 \&$ show $=$ clanak
8. World Health Organization. Obesity. (Internet). Geneva: WHO; 2020. (accessed on 29 Mar 2020). Available at: https://www.who.int/ health-topics/obesity\#tab=tab_1

9. Škrabić V, Unić Šabašov I. Učestalost i specifičnosti debljine u predškolskoj dobi., University Hospital of Split, Pediatric Unit. (Internet). Split; 2014. (accessed on 29 Mar 2020). Available at: https://bib.irb.hr/datoteka/737336. Uestalost_i_specifinosti_debljine_u_predkolskoj_dobi.pdf

10. Croatian Institute for Public Health. Croatian Obesity Awareness Day (in Croatian). Zagreb: Croatian Institute for Public Health; 2019. (accessed on 29 Mar 2020). Available at: https://www.hzjz.hr/sluzba-promicanjezdravlja/hrvatski-dan-osvijestenosti-o-debljini-16-03-2019/

11. Canadian Diabetes Association. Body mass index (BMI) calculator. (Internet). Toronto: The Canadian Diabetes Association; 2021. (citied 18 Jul 2021). Available at: https://www.diabetes.ca/managing-my-diabetes/tools---resources/body-mass-index-(bmi)-calculator

12. Židić N. Značenje stanja uhranjenosti predškolske djece za izradbu jelovnika u dječjem vrtiću (diploma thesis) Split: University of Split, University Department of Health Studies; 2021. (accessed on 14 Jul 2021). Available at: https://repozitorij.svkst.unist.hr/islandora/ object/ozs $\% 3 \mathrm{~A} 900$

13. Centers for Disease Control and Prevention. BMI Percentile Calculator for Child and Teen. (Internet) (accessed on 17.07.2021). Available at: https://www.cdc.gov/healthyweight/bmi/ calculator.html

14. Canning P. M, Courage M. L, Frizzell L. M. Prevalence of overweight and obesity in a provincial population of Canadian preschool children. (Internet). CMAJ.2004 (accessed on 07 Sep 2020); 171(3):240-242 (accessed on 07 Sep 2020). Available at: https://www.ncbi.nlm.nih. gov/pmc/articles/PMC490073/

15. Cresso I. Prehrambene navike djece predškolske dobi (final thesis). Pula: University of Juraj Dobrila, Faculty of Educational Sciences; 2017. (Internet). (accessed on 06 Oct 2020). Available at: https://repozitorij.unipu.hr/islandora/object/unipu\%3A1676

16. Adžamić M. Zaštita i njega djece predškolske dobi (final thesis). Zagreb: University of Zagreb, Faculty of Teacher Education, Department for Preschool Education; 2018. (Internet). (accessed on 6 Oct 2020). Available at: https://repozitorij.ufzg.unizg.hr/islandora/ object/ufzg\%3A740/datastream/PDF/view

17. Živković D. Utjecaj tjelesne aktivnosti na kvalitetu života djece i adolescenata (final thesis). Osijek: Josip Juraj Strossmayer University of Osijek, Faculty of Social Sciences and Humanities, Undergraduate Studies of Philosophy; 2015. (Internet). (accessed on 6 Oct 2020). Available at: https://zir.nsk.hr/islandora/object/ ffos $\% 3 \mathrm{~A} 43 /$ datastream/PDF/view 
18. Mihić, I. Načela sestrinstva u vrtiću. Dijete, vrtić, obitelj. Journal for education of preschool children for professionals and parents, 2010; 61: $30-2$.

19. Državni pedagoški standard predškolskog odgoja i naobrazbe, Official Gazette, no. 63/08 (Internet). (accessed on 24 Nov 2020). Available at: https://narodne-novine.nn.hr/clanci/ sluzbeni/2008_06_63_2128.html
20. Verbanac D. O prehrani. Što kada i zašto jesti. Zagreb: Školska knjiga; 2004.

21. Kovač K. Utjecaj tjelesnog vježbanja na funkcionalne sposobnosti djece predškolske dobi (final thesis). Zagreb: Universisty of Zagreb, Faculty of Teacher Education, Department for preschool studies; 2018. (Internet). (accessed on 8 Sep 2020). Available at https://repozitorij. ufzg.unizg.hr/islandora/object/ufzg:935
22. Jordanić K. Pravilna prehrana predškolskog djeteta-preporučeno i stvarno (final thesis) Zagreb: University of Zagreb, Faculty of Teacher Education, Department for preschool studies; 2015. (Internet). (accessed on 13 Oct 2019). Available at: https://repozitorij.ufzg.unizg.hr/ islandora/object/ufzg\%3A51/datastream/PDF/ view

\section{Summary}

\section{USPOREDBA STANJA UHRANJENOSTI MEĐU DJEČJIM VRTIĆKIM SKUPINAMA U SPLITU}

Nela Židić, Nada Tomasović Mrčela

Cilj je utvrditi postoji li u splitskim dječjim vrtićima razlika u stupnju uhranjenosti djece po dobnim skupinama što bi impliciralo na preinake kcal (kilokalorijskih) vrijednosti dnevnih jelovnika koji su jednaki za sve dobne skupine.

Ispitanici i metode: Istraživanje se provodilo tijekom lipnja 2020. u Dječjem vrtiću (DV) "Grigor Vitez" u Splitu na način da su roditelji djece dobrovoljno ispunjavali anketni upitnik uz jamčenu anonimnost. Iz anketnog upitnika korišteni su podaci o visini $i$ težini djeteta za izračun pokazatelja uhranjenosti: indeksa tjelesne mase (ITM) i percentilne krivulje indeksa tjelesne mase (\% ITM), definirane prema spolu i uzrastu (u daljnjem tekstu: percentili).

Rezultati: Analizirani su podaci za 128 djece u dobi 3-6,99 godina Dječjeg vrtića "Grigor Vitez". Djeca se prema dobnim skupinama (3-3,99 god., 4-4,99 god., 5-5,99 god., 6-6,99 god.) u dječjem vrtiću značajno ne razlikuju po stupnju uhranjenosti. $U$ dobnoj skupini djece od 6,00-6,99 godina utvrđen je najveći prosječni percentil (60,30) koji je u odnosu na prosječnu vrijednost percentila djece starosne dobi 3,00-3,99 godina veći za 12,89 bodova, dok postojanje razlike testiranjem nije utvrđeno ( $F=0,936$; $p=0,426)$.

Zaključak: Uspoređene su samo percentilne vrijednosti među vrtićkim skupinama te se iz toga može zaključiti da obroci možda imaju odgovarajuće energetske vrijednosti, koje je potrebno provjeriti analizom jelovnika, te usporedbom istih s preporukama.

Ključne riječi: STANJE UHRANJENOSTI PREDŠKOLSKE DJECE, JELOVNICI U DJEČJEM VRTIĆU 